\title{
A quantitative assessment of the cryptobenthic fish assemblage at deep littoral cliffs in the Mediterranean
}

\author{
Igor Glavičić ${ }^{1}$, Dejan Paliska ${ }^{2}$, Alen Soldo ${ }^{1}$, Marcelo Kovačić ${ }^{3}$ \\ ${ }^{1}$ Department of Marine Studies, University of Split, Livanjska 5, HR-21000 Split, Croatia. \\ ${ }^{2}$ MEDIFAS-Mediterranean Institute for Advance Studies, Šempeter pri Gorici, Slovenia \\ ${ }^{3}$ Natural History Museum Rijeka, Lorenzov prolaz 1 HR-51000 Rijeka, Croatia. E-mail: marcelo@ prirodoslovni.com.
}

\begin{abstract}
Summary: The present study provides the first quantitative assessment of cryptobenthic fish species diversity and abundance on hard bottoms below $20 \mathrm{~m}$ depth by examining Mediterranean underwater reefs with deep vertical cliffs. Quantitative sampling was performed at depths down to about $45 \mathrm{~m}$ and yielded 220 cryptobenthic and 61 epibenthic individuals belonging to 21 species, showing that the cryptobenthic fishes highly outnumbered the epibenthic individuals. The study highlights the high diversity and abundance of this unexplored part of the benthic fish community. The cryptobenthic fish assemblage was dominated by the family Gobiidae in terms of both biodiversity ( $>60 \%$ of all species) and abundance ( $>90 \%$ of all specimens). Fish species previously considered rare were present and some of them were even numerous in this assemblage. Three out of fourteen recorded habitat variables (depth, rocky cliff surface area vs. the bottom of the cliff area, and the presence of sand as the bottom substrate) were identified as significant for species occurrence. Species were generalist in their choice of shelters since the size and quantity of semi-caves, caves, cavities and even bio-cover type had no significant influence on the species distribution and abundance.
\end{abstract}

Keywords: cryptobenthic fishes; multivariate analysis; benthos; littoral zone; underwater cliffs; scuba diving.

Evaluación cuantitativa de la comunidad de peces criptobenónicos en los acantilados profundos del litoral Mediterráneo

Resumen: Este trabajo presenta una primera evaluación cuantitativa de la diversidad y abundancia de los peces criptobentónicos de fondos duros por debajo de $20 \mathrm{~m}$ de profundidad, como ejemplo de acantilados litorales sumergidos del Mediterráneo. Se realizó un muestreo a profundidades cercanas a $45 \mathrm{~m}$ de profundidad y se obtuvieron 220 individuos criptobentònicos y 61 epibentónicos pertenecientes a 21 especies. El estudio pone de manifiesto la gran diversidad y abundancia de esta fracción inexplorada de la comunidad de peces bentónicos. La familia Gobiidae domina la comunidad de peces criptobentónicos en biodiversidad y abundancia ( $>60 \%$ y $>90 \%$ del total de especies respectivamente). Se han observado especies de peces de este grupo consideradas raras, incluso algunas son numerosas. Tres de cada 14 variables registradas del hábitat (profundidad, superficie rocosa del acantilado $v s$ fondo del acantilado y presencia de arena en el sustrato del fondo) fueron significativas para la presencia de las especies. En la elección de los refugios las especies fueron generalistas ya que el tamaño y la cantidad de semicuevas, cuevas, cavidades e incluso tipos de cubierta biológica no tienen influencia significativa en la distribución y abundancia de las especies.

Palabras clave: peces criptobentónicos; análisis multivariante; bentos; zona litoral; acantilados sumergidos; submarinismo.

Citation/Como citar este artículo: Glavičić I., Paliska D., Soldo A., Kovačić M. 2016. A quantitative assessment of the cryptobenthic fish assemblage at deep littoral cliffs in the Mediterranean. Sci. Mar. 80(3): 329-337. doi: http://dx.doi. org/10.3989/scimar.04307.23A

Editor: M. Demestre.

Received: June 29, 2015. Accepted: April 29, 2016. Published: September 24, 2016.

Copyright: () 2016 CSIC. This is an open-access article distributed under the terms of the Creative Commons Attribution (CC-by) Spain 3.0 License.

\section{INTRODUCTION}

In rocky reefs and coralligenous habitats throughout the world, fish assemblages are important components of coastal biodiversity, contributing crucially to ecosystem functioning and representing important marine resources for humans (Ackerman and Bellwood 2000, Bussotti and Guidetti, 2009). Various underwater visual census (UVC) methods have often been used in ichthyological research, especially on hard littoral bottoms where most widespread methods for the quantitative assessment of fish assemblages, such as capture meth- 
ods using trawls and other fishing gear, are hard to use (Harmelin-Vivien and Francour 1992, Lipej et al. 2003, Soldo and Glavičić 2013). However, it is confirmed that the standard UVC methods can miss a large number of cryptobenthic fish species (Ackerman and Bellwood 2000, Willis 2001, Smith-Vaniz et al. 2006, Kovačić et al. 2012). A cryptobenthic fish is a species (or a life history stage of a fish species) whose individuals exclusively or predominantly spend their lifetime in cryptobenthic microhabitats, i.e. in the restricted living spaces underneath the bottom surface of the substrate or biocover, with a physical barrier to open spaces (Kovačić et al. 2012). To gain a full understanding of how a fish assemblage is composed and structured on hard littoral bottoms, a study of small cryptobenthic and epibenthic species using destructive techniques is required. Quantitative studies on cryptobenthic fish communities are surprisingly rare worldwide and restricted to coastal reefs with depths of mainly 15 to 20 m (Prochazka 1998, Ackerman and Bellwood 2000, 2002, Willis 2001, Depczynski and Bellwood 2003, 2004, Smith-Vaniz et al. 2006, Beldade et al. 2006, Beldade and Gonçavles 2007, Kovačić et al. 2012). No quantitative research on cryptobenthic fish has been performed at or below $40 \mathrm{~m}$ depth (Kovačić et al. 2012), while only recently the methodology for the quantitative research at circalittoral depths was proposed by Glavičić and Kovačić (2016). Other quantitative studies of fish assemblages at deep rocky reefs, i.e. UVC using SCUBA diving with a rebreather, are very rare and limited to tropical seas (Brokovich et al. 2008). Studies that include destructive methods on fish assemblages have been performed at underwater reefs going deeper, i.e. below $40 \mathrm{~m}$ in tropical seas, but they used only qualitative methods (Feitoza et al. 2005, Pyle et al. 2008).

Destructive techniques, by definition, remove fishes from a particular area and have a harmful effect upon the fish under investigation (Ackerman and Bellwood 2000). The main destructive methods that have been used for the study of fish assemblages using SCUBA diving are ichthyocides and anaesthetics (Ackerman and Bellwood 2000, Kovačić et al. 2012). Ichthyocides, such as Rotenon, have a slow effect on fishes, e.g. Rotenone takes $10-15 \mathrm{~min}$ to asphyxiate them (Ackerman and Bellwood 2000). In the case of repeated samplings during SCUBA dives, sampling with Rotenone requires a lot of time, which is usually limited in deeper dives. Therefore, the use of the anaesthetic Quinaldine, following the procedure of Kovačić et al. (2012), was chosen for the present study as the most appropriate method with high space and time efficiency.

The aim of the present study was: 1) to continue the studies on unexplored Mediterranean littoral benthic habitats potentially harbouring cryptobenthic fishes, following proposals by Kovačić et al. (2012); 2) to provide the first quantitative assessment of cryptobenthic fish species diversity and abundance on hard bottoms below $20 \mathrm{~m}$ depth by studying the deep underwater vertical cliffs of the Mediterranean; and 3) to identify the environmental variables that best explain species distribution and abundance patterns in this habitat, and

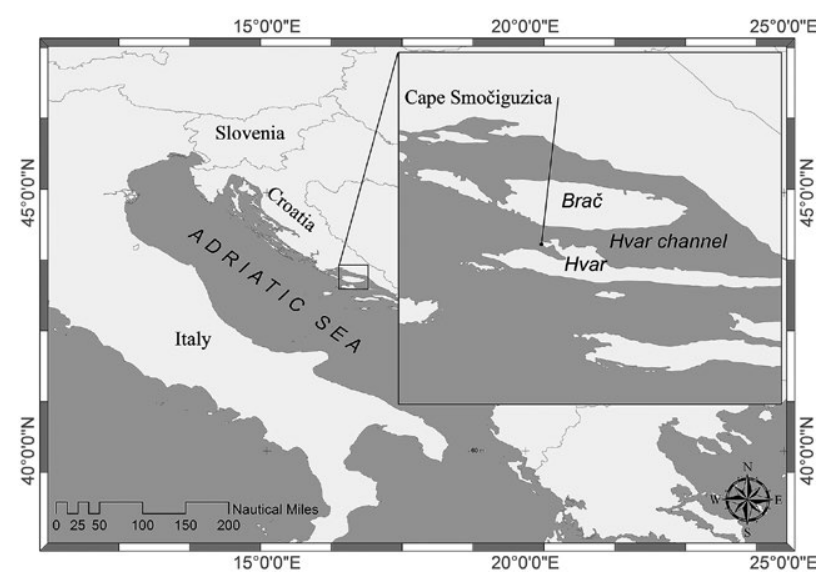

Fig. 1. - Map showing studied locality at Cape Smočiguzica.

that are therefore expected to shape the cryptobenthic fish community structure in this habitat.

\section{MATERIALS AND METHODS}

\section{Sampling location and time}

The study was carried out in the Hvar Channel, on the north coast of Hvar Island in the central eastern Adriatic (Fig. 1), during the warm season from June to October 2013. All sampling occurred during daytime, between 12 and 3 p.m. The locality studied was a steep underwater reef called Smočiguzica $\left(43^{\circ} 14.124^{\prime} \mathrm{N}\right.$, $\left.16^{\circ} 34.393^{\prime} \mathrm{E}\right)$, which is a part of the island of Hvar landmass, but more than $200 \mathrm{~m}$ away from the coastline. The reef surface structure is made of steep to vertical bedrock, with a few relatively large caves and a lot of smaller ones, and its base is surrounded by a sandy bottom. The reef is shaped as a truncated elliptical and oblique cone. The highest point of the reef is at $9.1 \mathrm{~m}$ depth, and the depth of the reef base varies from 43 to $61 \mathrm{~m}$. The most common biocenosis on the reef is the coralligenous community (Ballesteros 2006).

\section{Data collection}

The sampling was performed at depths of 15 to about $45 \mathrm{~m}$. To extend the amount of time that the divers could spend at underwater depths, all dives were performed using Nitrox 27. Two divers, both experienced and skilled in diving and in identifying fish and other marine species, were used each time.

A total of 50 one-square-metre bottom quadrants were sampled during 23 SCUBA dives. The number of quadrants performed in one dive varied from 1 to 3 depending on the depth. The protocol on the squares was modified from Kovačić et al. (2012). The anaesthetic used was Quinaldine diluted 1:15 with $96 \%$ ethanol and then mixed with sea water 1:5 in 750-mL bottles (modified from Kovačić et al. 2012). Two bottles were usually used for a square, i.e. the total volume of the deployed Quinaldineethanol solution was about $300 \mathrm{~mL} \mathrm{~m}^{-2}$. Specimens observed by visual census were defined as epibenthic specimens. Specimens found only after deploying anaesthetic were defined as cryptobenthic specimens. 
Table 1. - Descriptive statistics for all environmental variables. The recorded variables are marked in bold letters (n/a -not available).

\begin{tabular}{|c|c|c|c|c|c|c|}
\hline Environmental variable & $\begin{array}{c}\text { Variable } \\
\text { abbreviation }\end{array}$ & Min & $\operatorname{Max}$ & Median & $\begin{array}{l}\text { Interquartile } \\
\text { range }\end{array}$ & $\begin{array}{l}\text { Median abso- } \\
\text { lute deviation }\end{array}$ \\
\hline Depth & depth & 15 & 45 & 25 & 20 & 10 \\
\hline Rock wall base vs. rock wall (wall base=1; rock wall=0) & wallbase & 0 & 1 & 0 & & 0 \\
\hline Inclination $\left(0-19^{\circ}\right.$ not recorded; $\left.20-59^{\circ}=1 ; 60-74^{\circ}=2 ; 75-90^{\circ}=3\right)$ & inclinat & 1 & 3 & 3 & 1 & 0.72 \\
\hline Sand $(\%)$ & sand & 0 & 30 & 0 & 10 & 4.40 \\
\hline Gravel (\%) & gravel & $\mathrm{n} / \mathrm{a}$ & $\mathrm{n} / \mathrm{a}$ & $\mathrm{n} / \mathrm{a}$ & $\mathrm{n} / \mathrm{a}$ & $\mathrm{n} / \mathrm{a}$ \\
\hline Cobbles $(\%)$ & cobbles & $\mathrm{n} / \mathrm{a}$ & $\mathrm{n} / \mathrm{a}$ & $\mathrm{n} / \mathrm{a}$ & $\mathrm{n} / \mathrm{a}$ & $\mathrm{n} / \mathrm{a}$ \\
\hline Boulders (\%) & boulders & $\mathrm{n} / \mathrm{a}$ & $\mathrm{n} / \mathrm{a}$ & $\mathrm{n} / \mathrm{a}$ & $\mathrm{n} / \mathrm{a}$ & $\mathrm{n} / \mathrm{a}$ \\
\hline Bedrock (\%) & bedrock & 70 & 100 & 100 & 10 & 4.00 \\
\hline Phanerogams (\%) & phanero & $\mathrm{n} / \mathrm{a}$ & $\mathrm{n} / \mathrm{a}$ & $\mathrm{n} / \mathrm{a}$ & $\mathrm{n} / \mathrm{a}$ & $\mathrm{n} / \mathrm{a}$ \\
\hline Short tallus algae (\%) & shoalgae & 0 & 90 & 40 & 70 & 26.20 \\
\hline Long tallus algae $(\%)$ & lonalgae & $\mathrm{n} / \mathrm{a}$ & $\mathrm{n} / \mathrm{a}$ & $\mathrm{n} / \mathrm{a}$ & $\mathrm{n} / \mathrm{a}$ & $\mathrm{n} / \mathrm{a}$ \\
\hline Calcerous algae (\%) & calalgae & 0 & 90 & 50 & 58 & 22.80 \\
\hline Zoo cover $(\%)$ & zoocover & 0 & 10 & 10 & 0 & 1.60 \\
\hline No cover $(\%)$ & nocover & 0 & 30 & 0 & 10 & 4.60 \\
\hline Number of hidden spaces of entrance size 1: $5 \times 5-10 \times 10 \mathrm{~cm}$ & hidd1num & 0 & 4 & 2 & 2 & 1.08 \\
\hline Number of hidden spaces of entrance size 2: $10 \times 10 \mathrm{~cm}-20 \times 25 \mathrm{~cm}$ & hidd2num & 0 & 3 & 1 & 1 & 0.76 \\
\hline Number of hidden spaces of entrance size 3: $20 \times 25 \mathrm{~cm}-40 \times 50 \mathrm{~cm}$ & hidd3num & 0 & 3 & 0 & 1 & 0.58 \\
\hline Number of hidden spaces of entrance size $4:>40 \times 50 \mathrm{~cm}$ & hidd4num & 0 & 1 & 0 & 0 & 0.08 \\
\hline Sum of entrance surfaces of hidden spaces & hiddsumP & 0.5 & 32.5 & 6.5 & 14 & 7.32 \\
\hline
\end{tabular}

The following habitat characteristics were included in the recording sheet (modified from Kovačić et al. 2012): "Depth" (15, 25 and $35 \mathrm{~m}$, and the depth at the bottom of the cliff which was about $45 \mathrm{~m}$ ); "Inclination", as four estimated classes (gentle $\left[0-19^{\circ}\right]$, medium $\left[20-59^{\circ}\right]$, steep $\left.\left[60-74^{\circ}\right]\right)$ and very steep/ vertical $\left[75-90^{\circ}\right]$ ); "Position at the cliff" (rocky cliff surface vs. the base of the cliff); "Bottom substrate" and "Biocover", as in Kovačić et al. (2012); "Number of semicaves, caves and cavities", if present, as number of each of four estimated size classes of hidden spaces in each square by entrance size $\left(50-99 \mathrm{~cm}^{2}, 100-499\right.$ $\mathrm{cm}^{2}, 500-1999 \mathrm{~cm}^{2},>2000 \mathrm{~cm}^{2}$ ); and "Total surface of the entrances to the hidden spaces", estimated from the number and size of hidden spaces as percentages of the total surface in each square. The variables were estimated and recorded during dives (see order in protocol above) and most of them were later rechecked in the photos. The position of the collected cryptobenthic specimens in the habitat sensu Kovačić et al. (2012) was not recorded as most of the anaesthetised specimens were collected while floating along the surface of vertical cliffs. Thus, their exact origin and position at the bottom could not be known. Squares were selected to achieve an approximately equal representation of each depth i.e. 15, 25 and $35 \mathrm{~m}$, and the depth of the bottom of the cliff of about $45 \mathrm{~m}$ (the depth of the bottom of the cliff in the studied section of the cliff varied from 43 to $50 \mathrm{~m}$, and the square was always fixed at the bottom of the cliff on the border between bedrock and the soft sediment). The number of squares performed for each depth was 14 at $15 \mathrm{~m}, 12$ at $25 \mathrm{~m}, 12$ at $35 \mathrm{~m}$ and 12 at $45 \mathrm{~m}$. The position of the square along each isobath was random. The random numbers (ranging 1-50) were generated in advance and employed one by one from the list. Once a particular desired depth was reached going down along the lateral edge of the cliff, the divers moved a number of metres matching the particular random number on the cliff along the isobath. The point on the cliff reached was the position of the square where the $1 \times 1 \mathrm{~m}$ frame was fixed on the cliff. All collected specimens were killed, stored, measured and identified as in Kovačić et al. (2012).

\section{Data analysis}

Community composition of cryptobenthic and epibenthic fishes was analysed in order to identify environmental variables that best explain species distribution and abundance patterns in the total data set. Among the total number of possible environmental variables included in the field recording sheet, 14 variables were actually recorded during fieldwork (Table 1 , the recorded variables marked in bold letters). For the multivariate ordinations the CANOCO 4.5 computer package was used (Ter Braak and Šmilauer 1998). According to Gauch (1982), rare species typically have a minor influence on the results of multivariate statistics and can be perceived in ordination as outliers. However, some of the less abundant species in this research are stenotopic species with a low number of any published records and are, considering the poor knowledge of their influence in communities, interesting for study (Ahnelt and Kovačić 1997, Kovačić and Miller 2000, Kovačić 2008). Consequently, a compromise was chosen and species accounting for less than $1.2 \%$ ( $<4$ catches) of the total catch were omitted from the analysis (Table 2). To reveal prevailing patterns of response curves in relation to environment gradients, the data sets were exposed first to detrended correspondence analysis. The first axis gradient length $>4$ of standard deviation indicates strong nonlinear or unimodal responses, suggesting that canonical correspondence analysis (CCA) is the most appropriate method; values $<2$ of standard deviation indicate a monotonic response to the environmental gradients and redundancy analysis should be used (Ter Braak and Verdonschot 1995). In order to normalize the highly skewed distribution of species abundance, the data were $\log (x+1)$-transformed. The CCA was run with a focus on inter-species distances and the biplot scaling option. The option down-weight rare species was not selected because some of the abundant species are generally common and eurytopic littoral species, while several less numerous species are very rarely recorded stenotopic species and of unknown influence in communities, so their role should not be underes- 
Table 2. - The data from the bottom quadrats of $1 \mathrm{~m}^{2}(\mathrm{n}=50)$ showing recorded species with the number of cryptobenthic $(\mathrm{CB})(\mathrm{n}=220)$ and epibenthic $(\mathrm{EB})$ specimens $(\mathrm{n}=63)$ and the frequency of species occurrence at the squares. Species in bold letters $(\geq 4$ individuals) were included in quantitative data analysis.

\begin{tabular}{|c|c|c|c|c|c|}
\hline Family & Species (abbreviation) & $\begin{array}{c}\text { CB } \\
\text { specimens }\end{array}$ & EB specimens & $\begin{array}{l}\mathrm{CB} \text { frequency of } \\
\text { occurrence }\end{array}$ & $\begin{array}{l}\text { EB frequency of } \\
\text { occurrence }\end{array}$ \\
\hline Gobiidae & Corcyrogobius liechtensteini (Co li) & 73 & 0 & $74.0 \%$ & $0.0 \%$ \\
\hline Gobiidae & Odondebuenia balearica (Od ba) & 49 & 0 & $52.0 \%$ & $0.0 \%$ \\
\hline Gobiidae & Gobius auratus (Go au) & 30 & 46 & $36.0 \%$ & $56.0 \%$ \\
\hline Gobiidae & Didogobius splechtnai (Di sp) & 13 & 0 & $22.0 \%$ & $0.0 \%$ \\
\hline Blenniiidae & Parablennnius rouxi (Pa ro) & 13 & 0 & $20.0 \%$ & $0.0 \%$ \\
\hline Gobiidae & Chromogobius zebratus (Ch ze) & 9 & 0 & $16.0 \%$ & $0.0 \%$ \\
\hline Gobiidae & Thorogobius macrolepis (Th ma) & 8 & 1 & $10.0 \%$ & $2.0 \%$ \\
\hline Gobiidae & Zebrus zebrus (Ze ze) & 6 & 0 & $8.0 \%$ & $0.0 \%$ \\
\hline Gobiidae & Vanneaugobius dollfusi ( Va do) & 4 & 0 & $6.0 \%$ & $0.0 \%$ \\
\hline Pomacentridae & Chromis chromis & 3 & 0 & $6.0 \%$ & $0.0 \%$ \\
\hline Gobiidae & Gammogobius steinitzi & 3 & 0 & $4.0 \%$ & $0.0 \%$ \\
\hline Gobiidae & Gobius kolombatovici (Go ko) & 2 & 2 & $2.0 \%$ & $4.0 \%$ \\
\hline Gobiidae & Gobius vittatus (Go vi) & 1 & 4 & $4.0 \%$ & $8.0 \%$ \\
\hline Scorpaenidae & Scorpaena notata (Sc no) & 1 & 3 & $2.0 \%$ & $6.0 \%$ \\
\hline Gobiidae & Speleogobius trigloides & 1 & 1 & $2.0 \%$ & $2.0 \%$ \\
\hline Gobiesocidae & Apletodon incognitus & 1 & 0 & $2.0 \%$ & $0.0 \%$ \\
\hline Blenniiidae & Microlipophrys nigriceps & 1 & 0 & $2.0 \%$ & $0.0 \%$ \\
\hline Scorpaenidae & Scorpaena porcus & 1 & 0 & $2.0 \%$ & $0.0 \%$ \\
\hline Tripterygiidae & Tripterygion melanurum & 1 & 0 & $2.0 \%$ & $0.0 \%$ \\
\hline Gobiidae & Thorogobius ephippiatus & 0 & 3 & $0.0 \%$ & $6.0 \%$ \\
\hline Tripterygiidae & Tripterygion delaisi & 0 & 1 & $0.0 \%$ & $2.0 \%$ \\
\hline
\end{tabular}

timated in advance (Miller 1986, Jardas 1996, Ahnelt and Kovačić 1997, Kovačić and Miller 2000, Kovačić 2008). The first CCA was performed with all environmental variables and the forward selection procedure was then used to extract the variables incorporated in the final model. In order to avoid inflated significance values, redundant predictor variables, i.e. environmental variables showing high multicolinearity (VIF $>10$ ), were removed from the model. The significance of the canonical axes and of the environmental variables was determined using Monte Carlo permutation tests (with 499 permutations).

\section{RESULTS}

\section{Diversity, abundance and frequency of cryptobenthic and epibenthic fish species}

The total number of recorded cryptobenthic and epibenthic fish species in the bottom quadrats was 21 (Table 2). The epibenthic specimens belonged to 8 species and the cryptobenthic specimens belong to 19 species. In other words, 6 species were observed both in cryptobenthic and epibenthic positions and two infrequent species, leopard spotted goby, Thorogobius ephippiatus (Lowe, 1839) and Tripterygion delaisi Cadenat and Blanche, 1971, were found exclusively on the open surface. The family Gobiidae contributed to fish biodiversity with 13 species, more than a half of all the recorded species. Other five families were represented with only one or two species (Table 2). The average total abundance of cryptobenthic and epibenthic fishes in the bottom quadrats was $6.64 \pm 0.36$ ind. $\mathrm{m}^{-2}$ (mean \pm S.E.) and ranged from 3 to 17 ind. $\mathrm{m}^{-2}$. The cryptobenthic fish, with 220 individuals collected, highly outnumbered the 61 recorded epibenthic individuals. The twelve most abundant species with four or more individuals collected or recorded represented $94.3 \%$ of all individuals. The three most numerous species, Liechtenstein's goby Corcyrogobius liechtensteini (Kolombatović, 1891), Coralline goby Odondebuenia balearica (Pellegrin and Fage, 1907) and Golden goby Gobius auratus Risso, 1810, collectively made up $69.1 \%$ of all cryptobenthic specimens. The epibenthic individuals of a single species, G. auratus, represent $75.4 \%$ of all recorded epibenthic fish (Table $2)$. The most abundant species were exclusively present in cryptic positions, except for $G$. auratus, which was very common in both hidden spaces and open positions (Table 2). The species of the family Gobiidae contributed more than $90 \%$ to total fish abundance. The eight most numerous species with cryptobenthic individuals and individuals in general were also the most frequent species in quadrants, ranked from $C$. liechtensteini, recorded in about 3/4 of the quadrants, to the zebra goby, Zebrus zebrus (Risso, 1826), which was present in $8 \%$ of the quadrants (Table 2).

\section{Important habitat variables and habitat preferences of fish species}

The number of the environmental variables that were actually recorded in the field was smaller than expected (Table 1, the recorded variables marked in bold letters). Some bottom substrate and bottom cover variables that usually occur on littoral bottoms were missing in the specific environment of the vertical cliffs.

In the CCA analysis all 14 recorded environmental variables were initially considered. The first exploratory CCAs indicate that, although the global model with 14 environmental variables was statistically significant, some environmental variables were inter-correlated (Fig. 2A). After the removal of redundant variables, the second model was run with only 10 environmental variables (Fig. 2B). The Monte Carlo permutation test indicated that in both analyses the first axis and all other canonical axes were statistically significant (Tables 3 and 4). The first four canonical axes explained $82.2 \%$ 



Fig. 2. - CCA species-environment biplot for 14 (A) and 10 fish species (B) (biplot scaling). In the biplot (B), together, the first two axes explain $17.2 \%$ (horizontally $\lambda=0.302$; vertically $\lambda=0.179$ ) of the total inertia in the abundance and $58.2 \%$ of variance in the weighted averages and class totals of species with respect to environmental variables. Quantitative environmental variables are represented by arrows and nominal variable is indicated by a triangle, both with abbreviations in regular font. Hollow triangles and abbreviations in italics represent fish species. The abbreviations for variables are explained in Table 1, and for fish species in Table 2.

Table 3. - Outcome of CCA, using 14 environmental variables. Significant environmental variables are reported in Table 5.

\begin{tabular}{lcccc}
\hline Total inertia $=2.796$ & Axis 1 & Axis 2 & Axis 3 & Axis 4 \\
Sum of canonical eigenvalues $=0.844$ & 0.307 & 0.179 & 0.125 & 0.083 \\
\hline Eigenvalues & 0.830 & 0.757 & 0.637 & 0.565 \\
Species-environment (S-E) correlations & 11.0 & 17.4 & 21.9 & 24.8 \\
Cumulative \% variance of species data & 36.4 & 57.6 & 72.4 & 82.2 \\
Cumulative \% variance of S-E relation & 0.002 & & P (all canonical axes) $=0.008$ \\
Monte Carlo test (P-value, 499 permutations) & &
\end{tabular}

Table 4. - Outcome of CCA, using 10 environmental variables. Significant environmental variables are reported in Table 5.

Total inertia $=2.796$

Sum of canonical eigenvalues $=0.826$

\section{Eigenvalues}

Species-environment (S-E) correlations

Cumulative $\%$ variance of species data

Cumulative $\%$ variance of $S$-E relation

Monte Carlo test (P-value, 499 permutations)

\begin{tabular}{cccc} 
Axis 1 & Axis 2 & Axis 3 & Axis 4 \\
\hline 0.302 & 0.179 & 0.124 & 0.082 \\
0.824 & 0.756 & 0.637 & 0.562 \\
10.8 & 17.2 & 21.6 & 24.6 \\
36.5 & 58.2 & 73.3 & 83.2 \\
0.004 & \multicolumn{2}{c}{ P (all canonical axes) $=0.014$} \\
\hline
\end{tabular}

and $83.2 \%$ of species occurrence variation based on 14 and 10 environmental variables, respectively. The datasets with 14 and 10 environmental variables both identified the same three significant variables: depth $(\mathrm{P}=0.02$, forward selection), rocky cliff surface area vs. the bottom of the cliff area $(\mathrm{P}=0.008$, forward selection) and the presence of the sand as bottom substrate ( $\mathrm{P}=0.048$, forward selection) (Tables 3, 4 and 5). As can be seen in Table 5 , all other variables were not statistically significant. The first axis correlated positively with depth, calcareous algae and wall base, where the amount of calcareous algae is expected to increase with depth, and wall base is exclusively present at the deepest depth. The second axis may correlate with zoocover i.e. animal biocover.

The 12 species included in the model showed different relations to the three significant variables (Table 1 , the included species ( $>4$ catches) marked in bold letters; Fig. 2). Habitat preferences of the col- lected fishes were interpreted by the position of species centroids in the biplot related to significant variables and to other variables closely associated with three significant variables on the graph (Fig. 2). The highest influence among variables was exerted by the position on the cliff, where the group of gobiid species exclusively preferred the cliff base vs. the cliff itself (Gobius kolombatovici Kovačić and Miller, 2000, large scaled goby Thorogobius macrolepis (Kolombatović, 1891), Vanneaugobius dollfusi Brownell, 1978, Table 1, Fig. 2). Those species, as expected, were also more associated with the increasing depth and the increasing amount of calcareous algae, but surprisingly indifferent to another significant variable that was also present at the bottom of the cliff, the sand. In addition to these species found at the bottom of the cliff, the deeper bottom (and the calcareous algae cover) was also preferred by Didogobius splechtnai Ahnelt and Patzner, 1995 and by small red scorpionfish, Scorpaena notata 
Table 5. - Variation explained by 14 or 10 environmental variables. Marginal effect ( $\lambda$ 1) of environmental variable refers to eigenvalues fit if the corresponding variable was the only environmental variable in the model. The conditional effect ( $\lambda$ A) refers to the additional amount of explained variance in species distribution by the correspondent variable when selected by automatic forward selection in Canoco 4.5 . The obtained statistics of the Monte Carlo permutation test under the full model with 499 random permutations (P- value and F) are reported for each variable. Significant environmental variables $(\mathrm{P} \leq 0.05)$ are bold. The abbreviations are explained in Table 1.

\begin{tabular}{|c|c|c|c|c|c|c|c|}
\hline \multirow{2}{*}{ Variable } & \multirow{2}{*}{$\begin{array}{l}\text { Marginal Effects } \\
\qquad \lambda 1\end{array}$} & \multicolumn{6}{|c|}{ Conditional Effects after forward selection } \\
\hline & & $A^{1}$ & nmenta & $\mathrm{F}$ & $\lambda \Delta$ & nmenta & E \\
\hline & & & & & & & \\
\hline depth & 0.27 & 0.27 & 0.02 & 5.15 & 0.27 & 0.002 & 5.15 \\
\hline shoalgae & 0.24 & 0.03 & 0.744 & 0.68 & $\mathrm{n} / \mathrm{a}$ & $\mathrm{n} / \mathrm{a}$ & $\mathrm{n} / \mathrm{a}$ \\
\hline calalgae & 0.24 & 0.02 & 0.932 & 0.40 & 0.03 & 0.734 & 0.70 \\
\hline wallbase & 0.25 & 0.13 & 0.008 & 2.57 & 0.13 & 0.008 & 2.57 \\
\hline inclinat & 0.10 & 0.08 & 0.076 & 1.66 & 0.08 & 0.076 & 1.66 \\
\hline sand & 0.15 & 0.11 & 0.048 & 2.20 & 0.11 & 0.048 & 2.20 \\
\hline bedrock & 0.15 & $\mathrm{n} / \mathrm{a}$ & $\mathrm{n} / \mathrm{a}$ & $\mathrm{n} / \mathrm{a}$ & $\mathrm{n} / \mathrm{a}$ & $\mathrm{n} / \mathrm{a}$ & $\mathrm{n} / \mathrm{a}$ \\
\hline nocover & 0.15 & $\mathrm{n} / \mathrm{a}$ & $\mathrm{n} / \mathrm{a}$ & $\mathrm{n} / \mathrm{a}$ & $\mathrm{n} / \mathrm{a}$ & $\mathrm{n} / \mathrm{a}$ & $\mathrm{n} / \mathrm{a}$ \\
\hline hidd1num & 0.08 & 0.06 & 0.254 & 1.24 & 0.06 & 0.254 & 1.24 \\
\hline zoocover & 0.09 & 0.05 & 0.474 & 0.94 & 0.05 & 0.474 & 0.94 \\
\hline hidd2num & 0.08 & 0.04 & 0.618 & 0.81 & 0.04 & 0.618 & 0.81 \\
\hline hidd4num & 0.05 & 0.04 & 0.598 & 0.85 & 0.04 & 0.598 & 0.85 \\
\hline hidd3num & 0.03 & 0.01 & 0.996 & 0.21 & 0.02 & 0.996 & 0.23 \\
\hline hiddsumP & 0.03 & $\mathrm{n} / \mathrm{a}$ & $\mathrm{n} / \mathrm{a}$ & $\mathrm{n} / \mathrm{a}$ & $\mathrm{n} / \mathrm{a}$ & $\mathrm{n} / \mathrm{a}$ & $\mathrm{n} / \mathrm{a}$ \\
\hline
\end{tabular}

Rafinesque, 1810. Contrary to this, a strong association with the shallow depth within the studied range 15 to approx. $45 \mathrm{~m}$ depth was shown by Z. zebrus, and to some extent by Parablennnius rouxi (Cocco, 1833) and $O$. balearica. These three species with a preference for the shallow parts of the cliff were also associated with the steep inclination contrary to most of the species showing indifference to inclination. The remaining four species were more or less indifferent to the depth of the bottom. The bottom substrate was dominated by the bedrock and the only other recorded bottom substrate was sand, which was present in about half (54\%) of the quadrants, covering 5\%-30\% of their surfaces. An association with the presence of sand, i.e. with the mixed bottom of bedrock and sand, was evident for four gobiid species (Kolombatović's goby Chromogobius zebratus (Kolombatović, 1819), D. splechtnai, G. auratus, and striped goby, Gobius vittatus Vinciguerra, 1883). On the other hand, the three species preferring a steep inclination (O. balearica, $P$. rouxi and $Z$. zebrus) showed an avoidance of sand.

\section{DISCUSSION}

The present study is the first quantitative assessment of cryptobenthic fish species diversity and abundance at hard bottoms below $20 \mathrm{~m}$ of depth. It was performed on a Mediterranean underwater reef with vertical cliffs going down to about $45 \mathrm{~m}$ depth. The recorded fish assemblage is part of the Mediterranean infralittoral and shallow circalittoral ecozones, which are mostly occupied by coralligenous biocenoses (Table 1, quadrants with median of calcareous algae cover of $50 \%$ ) and to some degree by biocenoses of infralittoral algae (Bakran-Petricioli 2007, 2011). The necessity of a large number of longer dives at greater depths in order to obtain quantitatively useful data could be the reason for the lack of this kind of study in general. These studies need an extended diving time for the use of ichthyocides or anaesthetics, and for the larger number of quadrants necessary for quantitative analysis. The use of the anaesthetic Quinaldine, which takes just 2-3 min to asphyxiate fishes, provided better use of diving time, and the SCUBA diving protocol depending not just on compressed air but on other gas mixtures provided longer diving time. The chosen procedure of Kovačić et al. (2012), with $1 \mathrm{~m}^{2}$ squares, allowed for high space and time efficiency, while the quantity of Quinaldine used and the intensive examination of the substratum should have guaranteed a total census of present fishes.

The only published quantitative study (Kovačić et al. 2012 in the northern Adriatic Sea) that performed methodologically appropriate research on Mediterranean cryptobenthic fish communities was restricted to more shallow depths. Two other quantitative studies focusing on cryptobenthic fishes in the Mediterranean (La Mesa et al. 2004, 2006) used the visual census technique, a method which could not record "real" cryptobenthic fishes, i.e. fishes present in the cryptobenthic microhabitats, where they are never or rarely visible from the outside. Both studies were also depth-limited (to $23 \mathrm{~m}$ depth and $15 \mathrm{~m}$ depth, respectively). Two studies on cryptobenthic fish communities geographically closest to the Mediterranean were performed on the Atlantic coast of Portugal. Beldade et al. (2006) used only interference visual census with depth limits of $9.5 \mathrm{~m}$, while Beldade and Gonçavles (2007) combined interference visual census with limited use of the anaesthetic Quinaldine with depth limits of $11.2 \mathrm{~m}$. The qualitative studies of cryptobenthic fish communities in the Mediterranean were limited to the infralittoral zone and only one (Patzner 1999) reached $40 \mathrm{~m}$ depth, a depth similar to the present study. The qualitative studies of Patzner (1999) were performed in Ibiza, in the western Mediterranean Sea, using SCUBA diving and the anaesthetic Quinaldine, and it showed a high match in species composition with Adriatic researches. All 15 species recorded by Patzner (1999) were also recorded in the Adriatic researches (Kovačić et al. 2012, present research). Among them, 10 species were found in the present research and the 5 remaining shallow water species were recorded by Kovačić et al. (2012). Species biodiversity in Kovačić et al. (2012) was higher than in the present research $(27 v s .21$ species). However, that study covered a depth down to 20 $\mathrm{m}$, more diverse habitats and a higher total effort (76 
quadrants vs. 50 quadrants). About half of the species were the same as in the present study. Most of the remaining half of the species diversity in Kovačić et al. (2012) belonged to shallow water species of the families Blenniidae, Gobiidae and Gobiesocidae and, to a lesser degree, species of these families that do not occur on vertical and steep bedrocks (e.g. Lepadogaster candolii and Gobius bucchichi).

The average density was surprisingly similar between two studies performed on different habitats and depths: the present research had an average total abundance of cryptobenthic and epibenthic fish of $6.64 \pm 0.36$ ind. $\mathrm{m}^{-2}$ (mean $\pm \mathrm{SE}$ ), while in Kovačić et al. (2012) the median total abundance of cryptobenthic fish was 6 ind. $\mathrm{m}^{-2}$ and of epibenthic fish 1 ind. $\mathrm{m}^{-2}$. The cryptobenthic fish density is even higher on the tropical coral reef where Depczynski and Bellwood (2004) found a mean density of 11 ind. $\mathrm{m}^{-2}$. Both Mediterranean studies showed an abundance of cryptobenthic fish several times higher than that of epibenthic fish (in Kovačić et al. (2012) cryptobenthic fish/epibenthic fish ratio was 7.8; in the present research 3.6). In the present research 13 out of 21 species were found strictly in the cryptobenthic position, compared with 13 out of 27 species found by Kovačić et al. (2012). Therefore, the studies of benthic fish assemblages on infralittoral and circalittoral bottoms rich with shelters should not overlook the influence and role of cryptobenthic fishes in the biological community and in the benthic ecosystem.

The present study used two methods: visual census to study epibenthic fish and anaesthetic to study cryptobenthic fish. The part of the bottom fish assemblage that was not covered by these methods includes hyperbenthic fish and large epibenthic fish, the second one due to the limited size of individual squares, and the relative contribution of cryptobenthic fish to total benthic fish diversity is certainly lower than $62 \%$ and $48 \%$ from these two studies.

Despite the limited range of ecozones in this study, i.e. the lower infralittoral ecozone and the beginning of the circalittoral ecozone, one of three significant environmental variables that mostly contributed to variation in species occurrence (with an effect of 0.27 explained variance in species distribution) was the bottom depth. The presence of sand was another significant environmental variable that explained species distribution and abundance, with several gobiid species showing preferences for mixed bottoms and a few species showing an avoidance of sand. The third significant variable was the bottom of the cliff area, where some species occurred exclusively or mostly. It seems that the size and quantity of semicaves, caves and cavities, and even the biocover type as the second source of shelters, were without significant influence on species distribution and abundance, i.e. species were generalist in the choice of shelters. In a previous study of Kovačić et al. (2012), the three variables were highly significant for variation in species occurrence: depth, quantity of bedrock and presence of short thallus algae on boulders. Depth was, as in the present study, the variable contributing most strongly to variation in species occurrence in Kovačić et al. (2012). The dif- ferences in other significant and highly explanatory variables between the two studies could be the results of habitat differences, because not all the variables were present in both studies (e.g. the bottom of the cliff area in Kovačić et al. 2012). The depth dependence of cryptobenthic species composition for Mediterranean is also clearly visible in descriptive data in Patzner (1999, Fig. 1). The only other research that quantitatively studied, among other variables, the influence of depth on the cryptic fish community composition was also done in temperate waters, in South Africa, at depths of 0-20 m (Prochazka 1998) and showed depth to be the second most important environmental variable explaining cryptic fish community composition.

The indiscriminate use of the term cryptobenthic fishes in the past was criticized by Kovačić et al. (2012). We follow their definition of cryptobenthic fishes (provided here in the Introduction). The terms of cryptobenthic fish species and fish specimen in the cryptobenthic position should be clearly distinguished (see Material and methods). For the general conclusions on species character, even the large number of samples is not enough: the data need to be from various habitats, seasons and parts of day to understand general species relationships to the habitat and behaviour. In the present study, among species included in the quantitative data analysis, specimens of $Z$. zebrus, $P$. rouxi, $O$. balearica, C. zebratus, D. splechtnai and C. liechtensteini were found exclusively in the cryptobenthic positions. For the four of them the results match those in Kovačić et al. (2012) and represent one more evidence for the cryptobenthic character of these species. The exclusively cryptic behaviour of $P$. rouxi in the present study was surprising compared with previous data and general knowledge on the species (Kovačić et al. 2012), while D. splechtnai was not collected by Kovačić et al. (2012). The group of species present at the cliff base (G. kolombatovici, T. macrolepis, $V$. dollfusi) preferred epibenthic positions close to shelters. Another group along the entire cliff surface $(G$. auratus, $G$. vittatus and $S$. notata) could be termed epicryptobenthic according to Kovačić et al. (2012), considering their ambivalent bottom position records that include open and hidden places. The exclusively cryptic sample of Chromis chromis in the present study is too small for any conclusion but intensive use of cryptic spaces by this hyperbenthic species was known (at least for juvenile fish) at night-time (Harmelin 1987) and was recently reported even in daylight (Kovačić et al. 2012).

Some of the species found in the present study are considered to be "rare", i.e. they have a limited number of total known records (summarized by Francour (2008) for D. splechtnai; Kovtun and Manilo (2013) for Steinitz's goby, Gammogobius steinitzi Bath, 1971; Francour and Mangialajo (2007) for G. kolombatovici; Fesser (1980) for Speleogobius trigloides Zander and Jelinek, 1976; Ahnelt and Kovačić (1997) for T. macrolepis; and Kovačić (2008) for $V$. dollfusi). Most of them have been described or rediscovered during the last two decades (D. splechtnai, G. kolombatovici, $T$. macrolepis, $V$. dollfusi) and two species were described 
in the 1970s (G. steinitzi and S. trigloides). In addition, several species recorded in the present study as abundant $(C$. liechtensteini, $O$. balearica) or common $(C$. zebratus, Z. zebrus) had until recently been considered rare or even very rare species, but the recent study of Kovačić et al. (2012) revealed them to be a common part of the cryptobenthic fish assemblage.

Potential and possible directions of future research on Mediterranean cryptobenthic fish communities, using quantitative sampling by SCUBA diving and anaesthetics were reviewed by Kovačić et al. (2012). They could be summarized as studies of cryptobenthic fish communities at different times of day, seasons or different habitats to those used in Kovačić et al. (2012). The quantitative data on the influence of night and the cold season on the behaviour of Mediterranean benthic fishes and on their utilization of cryptic spaces is still unknown for any habitat. The present study, with a median of cover of calcareous algae in quadrants of $50 \%$ (Table 1), mostly studied the coralligenous biocenoses. This habitat was poorly included in the quadrants during the study by Kovačić et al. (2012), so the two studies are quite complementary by depths and bottom types. Other Mediterranean infralittoral benthic habitats well known for their rich cryptobenthic fish fauna, but without any quantitative data on this fauna, are Posidonia oceanica meadows and Cystoseira forests (Patzner 1999, Hofrichter and Patzner 2000). Future quantitative studies on cryptobenthic fishes should also target these two valuable and endangered Mediterranean habitats that have experienced a dramatic decline over the last decades in the Mediterranean (Boudouresque et al. 2003).

\section{ACKNOWLEDGEMENTS}

We are grateful to Robert A. Patzner for his review of the manuscript and Eva Jakupčević, Ivana Štambuk and Rob Rowlands for proofreading the English. We also thank the MARES S.p.A. company for providing the diving computer, ICON HD, used during our research.

\section{REFERENCES}

Ackerman J.L., Bellwood D.R. 2000. Reef fish assemblages: a reevaluation using enclosed rotenone stations. Mar. Ecol. Progr. Ser. 206: 227-237. http://dx.doi.org/10.3354/meps206227

Ackerman J.L., Bellwood D.R. 2002. Comparative efficiency of clove oil and rotenone for sampling tropical reef fish assemblages. J. Fish Biol. 60: 893-901. http://dx.doi.org/10.1111/j.1095-8649.2002.tb02416.x

Ahnelt H., Kovačić M. 1997. A northern Adriatic population of Thorogobius macrolepis (Gobiidae). Cybium 21: 149-162.

Bakran-Petricioli T. 2007. Marine habitats: Manual for inventory, mapping and monitoring (in Croatian). Državni zavod za zaštitu prirode, Zagreb, Croatia, $56 \mathrm{pp}$.

Bakran-Petricioli T. 2011. Manual for determination of marine habitats in Croatia according to EU Habitat Directive (in Croatian). Državni zavod za zaštitu prirode, Zagreb, Croatia, 184 pp.

Ballesteros E. 2006. Mediterranean coralligenous assemblages: a synthesis of present knowledge. Oceanogr. Mar. Biol. Annu. Rev. 44: 123-195. http://dx.doi.org/10.1201/9781420006391.ch4

Beldade R., Erzini K., Gonçalves E.J. 2006. Composition and temporal dynamics of a temperature rocky cryptobenthic fish assemblage. J. Mar. Biol. Ass. UK 86: 1221-1228. http://dx.doi.org/10.1017/S0025315406014226

Beldade R., Gonçalves E.J. 2007. An interference visual census technique applied to cryptobenthic fish assemblages. Vie Milieu 57: 61-65.

Boudouresque C.F., Ruitton S., Verlaque M. 2003. Anthropogenic impacts on marine vegetation in the Mediterranean. In: Proceeding of the Second Mediterranean Symposium on marine vegetation (Athens, 12-13 December 2003). Regional Activity Centre for Specially Protected Areas, Tunis, pp. 34-54.

Brokovich E., Einbinder S., Shashar N., et al. 2008. Descending to the twilight-zone: changes in coral reef fish assemblages along a depth gradient down to $65 \mathrm{~m}$. Mar. Ecol. Progr. Ser. 371: 253-262. http://dx.doi.org/10.3354/meps07591

Bussotti S., Guidetti P. 2009. Do Mediterranean fish assemblages associated with marine caves and rocky cliffs differ? Est. Coast Shelf Sci. 81: 65-73. http://dx.doi.org/10.1016/j.ecss.2008.09.023

Depczynski M., Bellwood D.R. 2003. The role of cryptobenthic reef fishes in coral reef trophodynamics. Mar. Ecol. Progr. Ser. 256: 183-191. http://dx.doi.org/10.3354/meps256183

Depczynski M., Bellwood D.R. 2004. Microhabitat utilisation patterns in cryptobenthic coral reef fish communities. Mar. Biol. 145: 455-463. http://dx.doi.org/10.1007/s00227-004-1342-6

Feitoza B.M., Rosa R.S., Rocha L.A. 2005. Ecology and zoogeography of deep-reef fishes in northeastern Brazil. Bull. Mar. Sci. 76: 725-742.

Fesser R. 1980. Zusätzliche Beschreibung von Speleogobius trigloides Zander und Jelinek (1976) (Gobiidae, Perciformes), sowie neue Fundorte und Freilandbeobachtungen. Verh. Zool.Bot. Ges. Wien 118/119: 123-126.

Francour P. 2008. First records of Didogobius splechtnai along the French Mediterranean coast and additional comments about $D$. schlieweni. AIeP 38: 139-141. http://dx.doi.org/10.3750/AIP2008.38.2.09

Francour P., Mangialajo L. 2007. Gobius kolombatovici, a common species of Gobiidae in the north-western Mediterranean Sea? Cybium 31: 389-390.

Gauch H.G. 1982. Multivariate Analysis in Community Ecology. Cambridge Univ. Press, Cambridge, UK, 298 pp. http://dx.doi.org/10.1017/CBO9780511623332

Glavičić I., Kovačić M. 2016. A quantitative sampling method for assessment of deep cryptobenthic ichthyofauna using trimix diving. AIeP 46: 43-47. http://dx.doi.org/10.3750/AIP2016.46.1.06

Harmelin J-G. 1987. Structure et variabilité de l'ichtyofaune d'une zone rocheuse protégé en Méditerraneé (par national de PortCros, France). PSZNI: Mar. Ecol. 8: 263-284. http://dx.doi.org/10.1111/j.1439-0485.1987.tb00188.x

Harmelin-Vivien M.L., Francour P. 1992. Trawling or visual censuses? Methodological bias in the assessment of fish populations in seagrass beds. PSZNI: Mar. Ecol. 13: 41-51. http://dx.doi.org/10.1111/j.1439-0485.1992.tb00338.x

Hofrichter R., Patzner R.A. 2000. Habitat and microhabitat of Mediterranean clingfishes (Teleostei: Gobiesociformes: Gobiesocidae). PSZN: Mar. Ecol. 21: 41-53. http://dx.doi.org/10.1046/j.1439-0485.2000.00689.x

Jardas I. 1996. Adriatic Ichthyofauna (in Croatian). Školska knjiga, Zagreb, Croatia, 533 pp.

Kovačić M. 2008. Live colouration, morphology and habitat of Vanneaugobius dollfusi (Gobiidae) in the northern Adriatic Sea. J. Fish Biol. 73: 1019-1023. http://dx.doi.org/10.1111/j.1095-8649.2008.01918.x

Kovačić M., Miller P.J. 2000. A new species of Gobius (Teleostei: Gobiidae) from the northern Adriatic Sea. Cybium 24: 231-239.

Kovačić M., Patzner R.A., Schliewen U.K. 2012. A first quantitative assessment of the ecology of cryptobenthic fishes in the Mediterranean Sea. Mar. Biol. 159: 2731-2742. http://dx.doi.org/10.1007/s00227-012-2030-6

Kovtun A.O., Manilo L.G. 2013. Mediterranean fish Gammogobius steinitzi Bath, 1971 (Actinopterygii: Perciformes: Gobiidae) A new representative of the Black Sea ichthyofauna. AIeP 43: 307-314. http://dx.doi.org/10.3750/AIP2013.43.4.08

La Mesa G., Micalizzi M., Giaccone G., et al. 2004. Cryptobenthic fishes of the "Ciclopi Islands" marine reserve (central Mediterranean Sea): assemblage composition, structure and relations 
with habitat features. Mar. Biol. 145: 233-242. http://dx.doi.org/10.1007/s00227-004-1315-9

La Mesa G., Di Mucchiuo S., Vacchi M. 2006. Structure of a Mediterranean cryptobenthic fish community and its relationships with habitat characteristics. Mar. Biol. 149: 149-167. http://dx.doi.org/10.1007/s00227-005-0194-Z

Lipej L., Orlando Bonaca M., Šiško M. 2003. Costal fish diversity in three marine protected areas in the gulf of Trieste (Northern Adriatic). Mar. Ecol. 24: 259-273. http://dx.doi.org/10.1046/j.1439-0485.2003.00843.x

Miller P.J. 1986. Gobiidae. In: Whitehead P.J.P., Bauchot M.L., et al. (eds), Fishes of the North-eastern Atlantic and the Mediterranean 3. UNESCO, Paris, pp. 1019-1085.

Patzner R.A. 1999. Habitat utilization and depth distribution of small cryptobenthic fishes (Blenniidae, Gobiesocidae, Gobiidae, Tripterygiidae) in Ibiza (western Mediterranean Sea). Environ. Biol. Fish. 55: 207-214. http://dx.doi.org/10.1023/A:1007535808710

Prochazka K. 1998. Spatial and trophic partitioning in cryptic fish communities of shallow subtidal reefs in False Bay, South Africa. Environ. Biol. Fish. 51: 201-220.

http://dx.doi.org/10.1023/A:1007407200708
Pyle R.L., Earle J.L., Greene B.D. 2008. Five new species of the damselfish genus Chromis (Perciformes: Labroidei: Pomacentridae) from deep coral reefs in the tropical western Pacific. Zootaxa 1671: 3-31.

Smith-Vaniz W.F., Jelks H.L., Rocha L.A. 2006. Relevance of cryptic fishes in the biodiversity assessments: A case study at Buck Island Reef National Monument, St. Croix. Bull. Mar. Sci. 79: $17-48$.

Soldo A., Glavičić I. 2013. Fish communities and their depth distribution at vertical corraligen reefs in the Adriatic. Rapp. Commis. Inter. Mer Medit. 40: 776

Ter Braak C.J.F., Verdonschot P.F.M. 1995. Canonical correspondence analysis and related multivariate methods in aquatic ecology. Aquatic Sci. 57: 255-289. http://dx.doi.org/10.1007/BF00877430

Ter Braak C.J.F., Smilauer P. 1998. Reference Manual and User's Guide to Canoco for Windows: Software for Canonical Community Ordination (Version 4). Microcomputer Power, Ithaca, New York, USA, 352 pp.

Willis T.J. 2001. Visual census methods underestimate density and diversity of cryptic reef fishes. J. Fish Biol. 59: 1408-1411. http://dx.doi.org/10.1111/j.1095-8649.2001.tb00202.x 